Baroutsis, A. (2019). Mapping the field of education research and media. In: Baroutsis, A., Riddle, S., and Thomson, P., Education research and the media: Challenges and possibilities (pp. 1-24). London: Routledge.

\title{
Mapping the field of education research and media
}

\author{
Aspa Baroutsis
}

\begin{abstract}
An emerging field of education research focuses on public discourse about education issues, in and through traditional and social media. This chapter provides an historical, statistical and thematic account of the archive of publications in this emerging field of education research and media. Following a review of the literature, the chapter maps the theoretical and methodological contributions which include theorising about mediatisation of education, the effects of moral panic, the inclusion and exclusion of particular voices, and the issues with notions of representation. Drawing on a thematic analysis, a discussion of the empirical conceptualisations of media constructions of education follows. The empirical findings can be categorised into literature about: education policy and politics; student assessments; schools, education systems and reforms; teachers' work; and children and young people. These studies outline the mediatisation of education, describing the messages about education that are being constructed and conveyed by print and social media. Such theorising about the influence of these media better enables better understandings for education stakeholders of this global publics.
\end{abstract}

An emerging field of education research focuses on public discourse about education issues, in and through traditional and social media. Traditional media refers to scholarship about education in broadcast media such as television and movies; as well as print media such as newspapers, both hardcopy and electronic formats (cf Baroutsis, 2016; Thomson, Blackmore, Sachs, \& Tregenza, 2003). More recently, as documented in this book, Education Research and the Media: Challenges and Possibilities, there is a growing prominence of the use of social media, such as FaceBook and Twitter, in and about education matters. Drawing on systematically retrieved selected literature, this chapter provides a comparative review by mapping the theoretical, methodological, and empirical elements in the publication archive. The compiled data seeks to identify key research addressing the mediatisation of education, expressing the entanglements and influences between media, education and education research. This timely review provides scholars with an overview of the research as well as significant commentary about the gaps and issues, thereby identifying future research directions.

Some of the first empirical literature in the field of education research and media is found in the early 1990s. Cunningham (1992) analysed how the press portrayed teachers and how this influenced public attitudes. The following year, Wallace (1993) identified the role of mass media in the education policy process. It was not until 2004 when the first journal special issue was published in the Journal of Education Policy, edited by Pat Thomson (also see Chapter 7), which focused entirely on education research and media. The introduction to the special issue stated:

Research is also now tangled up in media. Major funding bodies now expect grantees to make their findings public via media as well as other forms of publication. Researchers are routinely asked by journalists for their views on a range of government initiatives and social issues. Professional research associations are beginning to find ways to assist their members to deal with an unfamiliar communication genre that depends on the production of binaries, polarities, and condensed 'bytes'. Yet, as an object of research, the knot of policy, governance, and media is still largely the purview of journalism, media studies, cultural studies, and English scholars. (Thomson, 2004, p. 251) 
After almost 15 years, research and media continue their entanglements. The same text could be used to describe the current situation albeit with a greater degree of intensity as education institutions globally are asked to demonstrate their research engagement and impact.

Four other special issues have followed. In 2006, Michelle Stack and Deirdre Kelly edited a special issue titled 'Popular media, education and resistance' in the Canadian Journal of Education. One part of this special issues addressed how children, youth, and schools were 'represented' by media. Similarly, in 2007, Michelle Stack and Megan Boler edited another special issue in Policy Futures in Education, titled 'Media and policy in education'. While this special issue related to media education, there were a number of articles that focued on policy making and resistance. Also, in 2007, Cynthia Gerstl-Pepin (also see Chapter 6) edited a special issue titled 'Media, democracy, and the politics of education' in the Peabody Journal of Education. The introduction stated that the goal of the publication was: 'To draw attention to the important role that the media play in educational politics and to make a case for research that is attentive to the intersection of educational politics and media coverage' (Gerstl-Pepin, 2007, p. 1). The importance of understanding the entanglements of politics and media has only increased. The next special issue was in 2015, in Critical Education titled, 'News media, education, and the subversion of the neoliberal social imaginary'. The editors of this volume stated: 'This issue will explicate the various ways in which the mainstream media has helped facilitate and legitimate neoliberalism as a universal logic in reforming education, both locally and globally' (Ford, Porfilio, \& Goldstein, 2015, p. 2). Additionally, to date, there have been four books about education research and media: Education policy in the media by Thomas (2006); Literacy Wars by Snyder (2008); News media \& the neoliberal privatization of education, an edited collection by Wubbena, Ford, and Porfilio (2016), drawn from the Critical Education special issue; and Global university rankings and the mediatization of higher education by Stack (2016). A detailed overview of these and other volumes follows.

\section{Collecting the literature}

The systematic process of collecting literature framed around the goal of mapping the publications that span education and media. A search of published scholarly literature was conducted using library search engines that draw on education databases and Google Scholar. Additionally, searches were conducted via individual journals where literature was initially located on the topic. A difficulty I encountered here related to the choice of search terms. Often, the terms 'media' and 'education' yielded general publications that related to media arts or the teaching of media. Similarly, the inclusion of 'education research' and 'media' was only marginally more generative. Instead, a number of more advanced searches, utilising Boolean terms, were required that compiled various iterations of key words, for example, 'media representation', 'newspapers', 'twitter', 'school', 'education', or 'teachers'. As a secondary means of identifying publications in the field, a snowball method was used. This included identifying key words in retrieved papers and reviewing the reference list of each publication to help identify supplementary phrases used for searching for additional literature. This highlights one of the difficulties that researchers are likely to face when seeking to systematically collate literature in this emerging field.

Following the retrieval of publications, based on the outlined search term parameters, a refinement process was undertaken. This stage involved the application of four inclusion criteria (see Table 1). First, the subject matter was required to combine both an aspect of media and education. While there are many publications in the area of media communication and journalism, unless they related specifically to education, they were not included. 
Secondly, traditional print media and/or social media sources form the empirical basis of the publication's data set or the publication provides a theoretical or methodological discussion about education and media. Other traditional media such as radio or television are not included in this archive. Thirdly, publications had to have undergone a peer-review process; therefore, unpublished works or conference proceedings are not part of this archive. Finally, only publications written in English were included. In all, this literature review process identified 167 publications, with 23 being excluded, leaving 144 publications that form the corpus of data in this chapter.

Table 1.1 Inclusion criteria for literature searches

\begin{tabular}{|c|c|c|}
\hline CRITERIA: & INCLUDED PUBLICATIONS: & EXCLUDED PUBLICATIONS: \\
\hline $\begin{array}{l}\text { Subject } \\
\text { matter focus }\end{array}$ & - Related to an aspect of education & $\begin{array}{l}\text { - General publications about } \\
\text { media }\end{array}$ \\
\hline $\begin{array}{l}\text { Media } \\
\text { sources }\end{array}$ & $\begin{array}{ll}\text { - } & \text { Print or social media used as data } \\
\text { sets and/or } \\
\text { - } \\
\text { Analysed an aspect media } \\
\text { practice }\end{array}$ & $\begin{array}{l}\text { - Other sources such as radio, } \\
\text { television, movies etc. } \\
\text { - } \quad \text { General media research }\end{array}$ \\
\hline Published & $\begin{array}{l}\text { - Peer-reviewed journal, reviewed } \\
\text { professional journals, books }\end{array}$ & Theses, unpublished works \\
\hline Language & Written in English & Other languages \\
\hline
\end{tabular}

The selected publications were then categorised based on their media source and focus. First, texts were grouped into either those with traditional print or social media sources with $85 \%$ of the publications using traditional print media sources while $15 \%$ were derived from social media (see Table 2). Secondly, the texts were grouped based on their focus, that is, those that empirically used media sources as their data set and those without an empirical focus that theorised about an aspect of education and media. The empirical publications also frequently provided theoretical framings of these data which are described later in the chapter. The analysis found that $79 \%$ of publications had an empirical focus (see Table 2 ). These findings should be viewed in conjunction with the descriptive statistics outlined in the following section.

Table 1.2 Distribution of publications based on media sources $(n=144)$

\begin{tabular}{|l|c|c|c|}
\hline \multirow{2}{*}{$\begin{array}{c}\text { Source of } \\
\text { publication }\end{array}$} & \multicolumn{3}{|c|}{ Media-related focus of publication } \\
\cline { 2 - 4 } & Theoretical only & Theoretical and empirical & TOTAL \\
\hline Print media & $16 \%$ & $69 \%$ & $85 \%$ \\
\hline Social media & $5 \%$ & $10 \%$ & $15 \%$ \\
\hline TOTAL & $21 \%$ & $79 \%$ & \\
\hline
\end{tabular}

\section{Descriptive statistical overview of publications}

A simple descriptive statistical analysis maps the demographics of the publications in this education research and media archive. This includes: the distribution of publications based on publication dates; the type or format of the publications; the journal rankings; and the country the research was conducted in, if specified in the publication.

First, when compiled into decades, the analysis shows an exponential growth in the number of publications that report on education and media (see Figure 1). Based only on the literature derived from the outlined inclusion parameters, one of the first publications about traditional print media and education was in in the late 1970s (Gorton, 1979), while one of 
the first social media publications was almost 3 decades later (Luehmann, 2008). This gap is understandable given that the inception of print media sources such as newspapers date back to the early seventeenth century (Stephens, 2007), while the World Wide Web was invented centuries later in 1991. The discovery afforded many forms of networked communications including sites such as: 'Blogger (1999), Wikipedia (2001), Myspace (2003), Facebook (2004), Flickr (2004), YouTube (2005), Twitter (2006)' (van Dijck, 2013, p. 7). Therefore, the quantity of academic literature reflects the newness of these social media.

Figure 1.1 Distribution of education research and media publications by decade $(n=144)$

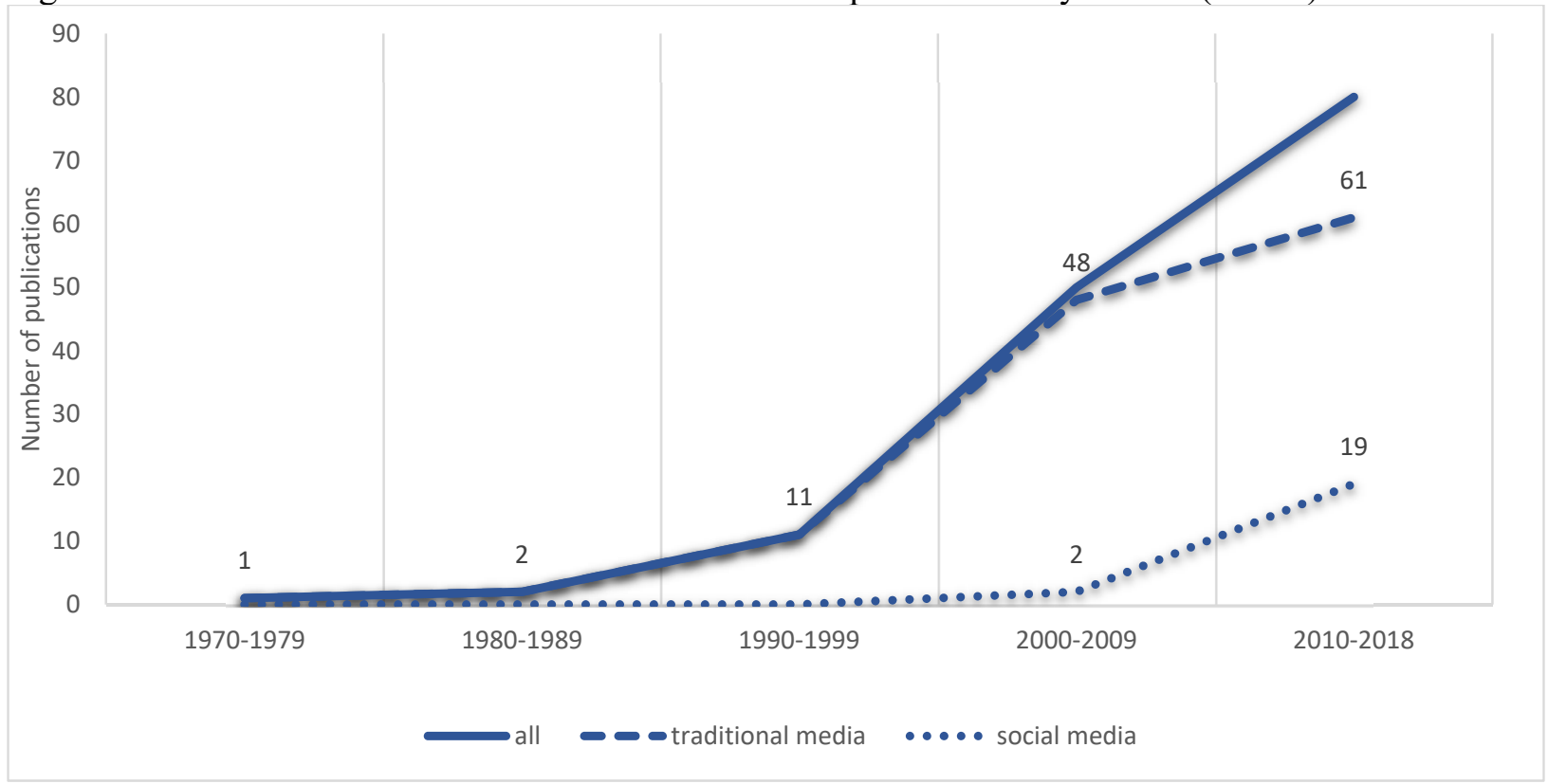

Secondly, based on the type of publications across both print and social media $(n=144), 88 \%$ are articles were found in peer-reviewed journals; $6 \%$ book chapters, $3 \%$ in reviewed professional journals; and $3 \%$ books. This signals the emerging nature of the education research and media field.

Thirdly, the preponderance of publications is in journals ( $\mathrm{n}=127)$; with $57 \%$ of the articles being published in high ranking journals (see Figure 2) based on the SCImago Journal Rank (SJR) indicator (www.scimagojr.com). 
Figure 1.2 Distribution of journal articles based on journal rank $(n=127)$

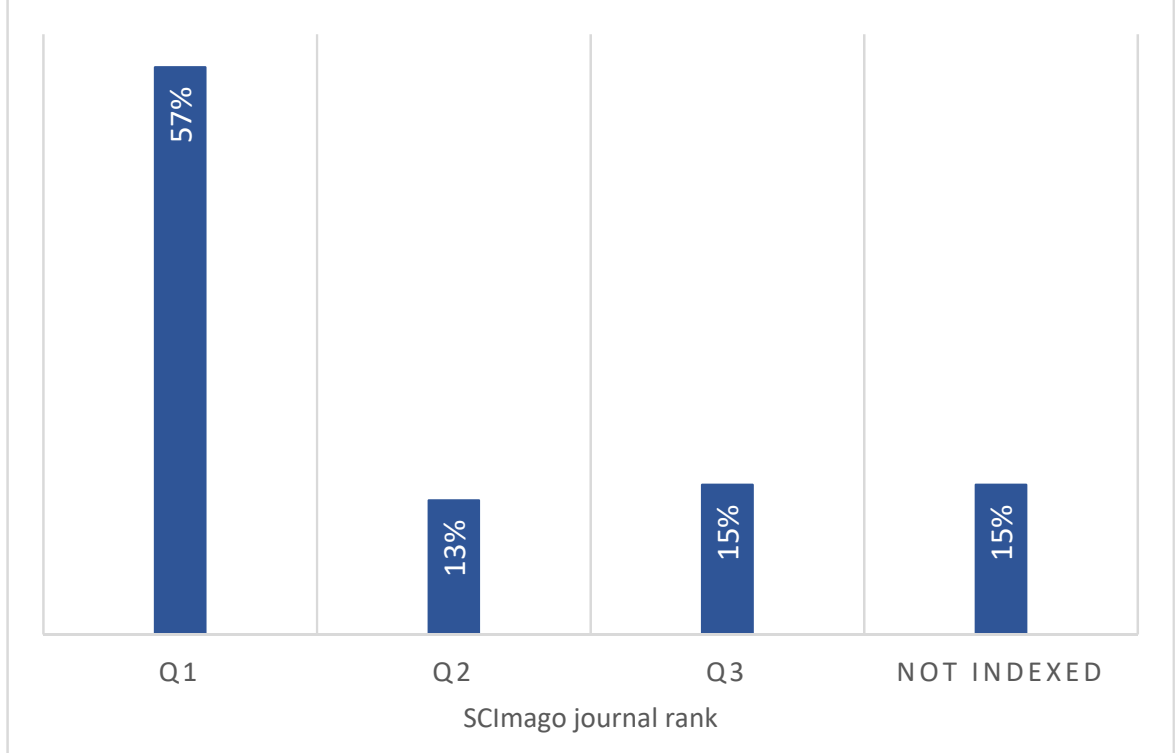

Finally, of the traditional print and social media-based empirical studies, there were 104 publications that indicated the country associated with the research. The remaining publications were not country-specific due to the nature of these media, that is, social media are global entities. Figure 3 identifies the distribution of publications. Of the studies using print media as empirical data, the largest collection of publications, 26\%, draws on Australian newspapers and contexts. This is followed by the USA with $23 \%$ of the publications and the UK with $14 \%$. Of interest here is that the Australian traditional media sector is oligopolistic, compared to that of the other two nations, and therefore tends to lack a diversity in both perspective and context (Cunningham, 2010). Research publications derived from these traditional print media are likely to reflect this lack of diversity. The studies using social media as empirical data were fewer, but as shown in Figure 1, these are increasing. Of those studies where a country was specified, the majority of these publications $(6 \%)$, were from the US context.

Figure 1.3 Distribution of publications based on country $(n=111)$

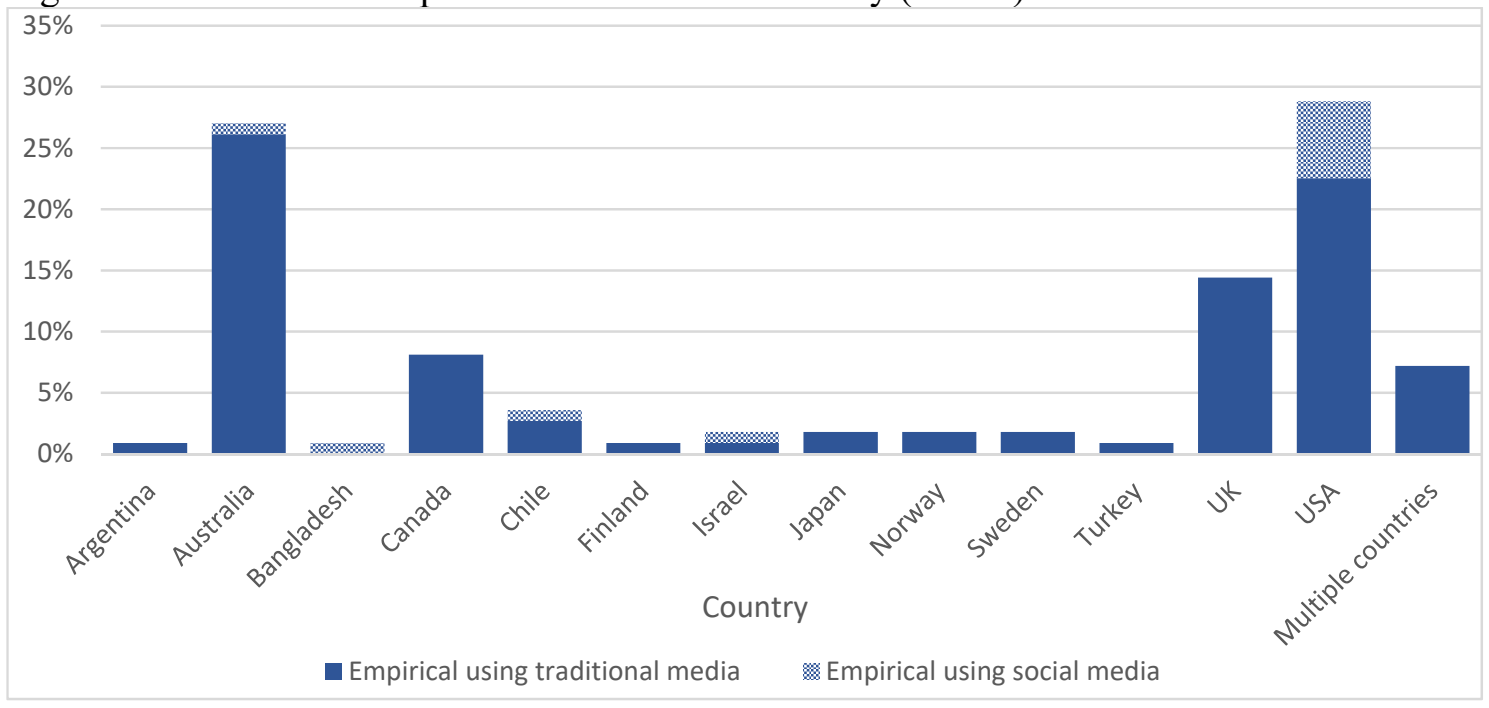


Baroutsis, A. (2019). Mapping the field of education research and media. In: Baroutsis, A., Riddle, S., and Thomson, P., Education research and the media: Challenges and possibilities (pp. 1-24). London: Routledge.

The descriptive statistics outlined in this section map the field of education research and media in simple terms, providing an historical overview of publications.

\section{Mapping education research and media conceptualisations}

This section draws on two research frames or conceptualisations to discuss the contributions of this archive to the field of education research and media. The first section maps the theoretical and methodological contributions, followed by a discussion of the empirical conceptualisations of media constructions of education.

\section{Theoretical and methodological conceptualisations of education research and media}

Media-focused education research, acutely draws on the neologism of mediatisation; a concept that is derived from media and communications research (cf Esser \& Stromback, 2014; Hepp, Brieter, \& Hasebrink, 2018). The first wave of mediatisation studies was predominantly concerned with 'mechanisation' and 'electrification' with the second wave being concerned with 'digitalisation' (Hepp et al., 2018). With digitisation, there has been a spread of technology-based communication media that permeates many aspects of society, from interacting with family, friends, and work colleagues; to engagement with learning and employment; to finance, retail and leisure activities; and governance, administration and politics.

Much of the early work in this area was by a small group of Australian scholars (cf Blackmore \& Thomson, 2004; Lingard \& Rawolle, 2004; Rawolle, 2005, 2010; Rawolle \& Lingard, 2010; Thomas, 1999, 2006) that developed the foundational concept by adopting and adapting understandings of mediatisation, drawing on the perspectives of education systems, stakeholders and practices. Education is a socio-cultural practice and as such, drawing on the work of Mazzoleni (2008), the mediatisation of education can be described as 'ways in which the media, which are vehicles of various types of messages (by which meaning is exchanged and negotiated), and society have made themselves mutually indispensable and unavoidably interrelated' (p. 1).

However, with the shift to digitalisation comes the opportunity for 'datafication'. This is a process that transforms regular information, such as a location or an online social interaction or other intangible aspects of everyday life, 'transforming it into a data format to make it quantified' allowing for the 'use the information in new ways, such as in predictive analysis' (Mayer-Schönberger \& Cukier, 2013, np). Take, for example, a book. When this is scanned from a hardcopy format it is digitised, but datafication indexes the book making it searchable (Mayer-Schönberger \& Cukier, 2013). In so doing, a user's actions in relation to the book become quantifiable and therefore, the user's habits can be analysed. Through the spread of technology-based communication media, we see the 'moulding force' of media in the social construction of realities (Hepp, 2013). It is this media influence on society that is the subject of mediatisation.

Theorising the influence of media better enables understandings for education stakeholders of this 'global public sphere' (Mazzoleni, 2015). Put simply, mediatisation is a conceptual tool that can interrogate and explain how these media shape public education discourse, both locally and globally. For example, Blackmore and Thorpe (2003) consider why particular education themes become foregrounded as issues and how government stakeholders mobilise media for strategic advantage during periods of education reform (also see Chapter 8). Similarly, Hattam, Prosser, and Brady (2009) outline the tactics used by policy and media actors to spin education news and the constitutive role these media play in 
the education policy process. In another example, Fenech and Wilkins (2017) consider how parent users of childcare may be differentially influenced by print media depending on type and format of the publication. Finally, Thapliyal (2018) critically analyses the effects of the strategic deployment of digital media to amplify and privilege particular perspectives.

Traditional print and social media inform education discourses; however, these media also create and influence, steer and shape education news and information for public consumption. In the outlined examples, mediatisation is conceptualised as a set of practices that impact the practices of others (Rawolle, 2010, p. 22). Mediatisation foregrounds 'media mentalities' and logics (Baroutsis, 2017) that are used to secure influence and the consequent 'mediatisation effects' (Rawolle \& Lingard, 2014), particularly the effects on democratic decision making (Rawolle, 2010). For example, I explore institutional and journalistic practices of agendisation, accountabilisation, factualisation, emphasisation, and sensationalisation in the reporting of teachers' work (Baroutsis, 2017). In other studies (Franklin, 2004; Gewirtz, Dickson, \& Power, 2004), scholars investigate the constitutive role of 'spin', the purposeful management of information, and its complex relationship with education policy which making it difficult for stakeholders and the public to distinguish the policies from the spin. Lingard and Rawolle (2004) draw on Bourdieu's (2011) critique of television to identify two logics of practice: circular circulation and permanent and structural amnesia, as they relate to education policy. Also drawing on Bourdieu, Phelan and Salter (2017) examine journalistic habitus and neoliberal logics of the marketised education agenda.

Similarly, there are social media logics and effects. In a digital age, the 'communication ecosystem' is shifting and transforming (Mazzoleni, 2017), as 'new media reconfigure and diversify processes of communication and interaction' (p. 142). Klinger and Svensson (2015) note that within this context evolves a 'network media logic[s]' which produces, distributes and uses media differently to mass media logics of practice. That is, for example, within social media networks, 'users are like intermediaries, distributing popular content' and media usage is based on highly selective 'interest-bound and like-minded peer networks' (p. 1246). Adhikary, Lingard, and Hardy (2018) show how Facebook has become a new platform for policy mediatisation through strategies such as the focus on the audio-visual dissemination of information and the use of emotional stimuli to influence public perceptions.

In reviewing the methodological conceptualisations of publications in the education research and media archive, these utilise four main tools for analysis: frame analysis, critical discourse analysis, content analysis, and social network. Frame analysis draws on the work of scholars such as Entman (1993) and Goffman (1986), who suggest media 'select some aspects of a perceived reality and make them more salient in a communicating text' (Entman, 1993, p. 53). Critical discourse analysis (CDA), drawing on the work of scholars such as Fairclough (2010) has a more linguistic focus and analyses language as social practice. Content analysis, an umbrella concept of approaches that include often technology-assisted analyses, both qualitative and quantitative, examines patterns in communications (cf Krippendorff, 2013). Social network analysis also draws on technology for large scale analysis of social networks, identifies relationship and interactions within social structures, visualised graphically through models and sociograms (also see Chapters 2 and 3).

These theoretical conceptualisations of media in education research, either overtly or surreptitiously, form the basis of many publications. Often, but not always, the theoretical undertones in education research are drawn from understanding and assumptions about media influences and logics of practice and have empirical manifestations within publications. However, it is through precise and detailed methodological work that education researchers can better align with scholarship in media and communication. 


\section{Empirical conceptualisations of education research and media}

Education research, when reporting on the findings of media analyses, tends to focus on six broad themes: education policy and politics; student assessments; schooling, education systems and reforms; teachers and their work; children and young people; and education research. Figure 4 identifies the distribution of all publications; however, only the first five themes will be discussed in this chapter. The majority of publications $(28 \%)$ focus on an element of schooling, education systems, and reforms; $23 \%$ of the archive focuses on teachers and aspects of teachers' work; $19 \%$ to international large-scale student assessments; $18 \%$ relates to education policy and politics; while $6 \%$ focus on children and young people. The latter, media and children and young people, identifies an area where future research should be considered. Finally, the smallest portion of publications provide a commentary about education research and media; however, these are usually not empirical accounts.

Figure 1.4 Distribution of education research publications based on thematic groups $(n=144)$

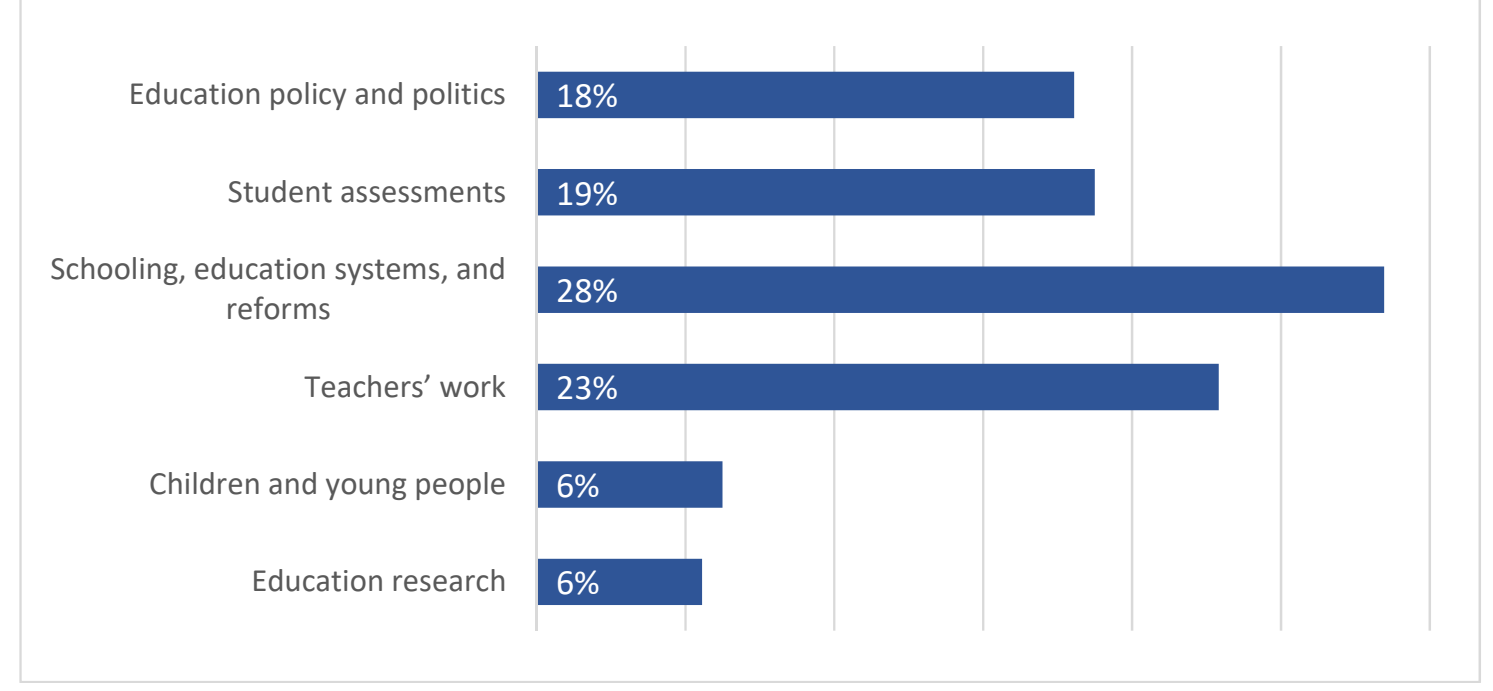

Table 3 identifies publications from the archive, that are indicative of these themes, with many of the authors being represented in this book. This section provides discussion and examples of these themes, along with identifying the notable exceptions to education research in the field thereby suggesting the scope for further research. 
Baroutsis, A. (2019). Mapping the field of education research and media. In: Baroutsis, A., Riddle, S., and Thomson, P., Education research and the media: Challenges and possibilities (pp. 1-24). London: Routledge.

Table 1.3 Representative examples of publications by country and theme

\begin{tabular}{|c|c|c|c|c|c|}
\hline Country & $\begin{array}{l}\text { Education policy } \\
\text { and politics }\end{array}$ & Student assessments & $\begin{array}{l}\text { Schooling, education } \\
\text { systems, and reforms }\end{array}$ & Teachers' work & $\begin{array}{l}\text { Children and young } \\
\text { people }\end{array}$ \\
\hline Argentina & & & Robert (2012) & & \\
\hline Australia & $\begin{array}{l}\text { Baroutsis (2016) } \\
\text { Blackmore and Thomson } \\
\text { (2004) } \\
\text { Lingard and Rawolle } \\
\text { (2004) } \\
\text { Rawolle (2005) } \\
\text { Thomas (2006) } \\
\end{array}$ & $\begin{array}{l}\text { Baroutsis and Lingard (2017) } \\
\text { Mockler (2013) }\end{array}$ & Thomas (1999) & Baroutsis (2017) & $\begin{array}{l}\text { Taylor (2018) } \\
\text { Mills (2004) }\end{array}$ \\
\hline Canada & & Stack (2007) & & "Greenberg (2004) & $\begin{array}{l}\text { Kelly (2006) } \\
\text { Gardam and Giles (2016) }\end{array}$ \\
\hline Chile & & & Cabalin (2015) & & Cabalin (2014) \\
\hline France & & Pons (2011) & & & \\
\hline Germany & & Martens and Niemann (2013) & & & \\
\hline Israel & & Yemini and Gordon (2017) & & & \\
\hline Japan & & Takayama (2008) & & & \\
\hline $\begin{array}{l}\text { Nordics: Norway, } \\
\text { Finland, Sweden }\end{array}$ & & $\begin{array}{l}\text { Fladmoe (2011) } \\
\text { Elstad (2009) }\end{array}$ & $\begin{array}{l}\text { Ronnberg, Lindgren, and } \\
\text { Segerholm (2013) }\end{array}$ & Edling (2015) & \\
\hline South Africa & & & & Alhamdan et al. (2014) & \\
\hline South Korea & & $\begin{array}{l}\text { Waldow, Takayama, and Sung } \\
(2014)\end{array}$ & & & \\
\hline Turkey & & Gur, Celik, and Ozoglu (2012) & & & \\
\hline UK & $\begin{array}{l}\text { Franklin (2004) } \\
\text { Pettigrew and MacLure } \\
\text { (1997) } \\
\text { Wallace (1993) } \\
\end{array}$ & $\begin{array}{l}\text { Grey and Morris (2018) } \\
\text { Murphy (2013) } \\
\text { Warmington and Murphy } \\
(2004)\end{array}$ & MacMillan (2002) & & \\
\hline USA & Anderson (2007) & $\begin{array}{l}\text { Steiner-Khamsi, Appleton, } \\
\text { and Vellani (2018) }\end{array}$ & Gerstl-Pepin (2002) & $\begin{array}{l}\text { Cohen }(2010) \\
\text { Goldstein (2011) } \\
\text { Ulmer }(2016) \\
\end{array}$ & $\begin{array}{l}\text { Chesky and Goldstein } \\
(2016)\end{array}$ \\
\hline
\end{tabular}


Baroutsis, A. (2019). Mapping the field of education research and media. In: Baroutsis, A., Riddle, S., and Thomson, P., Education research and the media: Challenges and possibilities (pp. 1-24). London: Routledge.

\section{Education policy and politics}

In addition to the publications outlined earlier that focus on mediatisation and media logics, a number of other important empirical studies are outlined here that focus on education policy and politics. These publications empirically demonstrate the effects of traditional print media on the education policy process. For example, I suggest that news media interpret school accountability policies thereby becoming part of the policy enactment process; reinforcing this rather than being part of policy contestation (Baroutsis, 2016). Elstad (2009) notes the 'negative bias' in the press that draws attention to schools that are performing badly in attainment measurements by naming, shaming and blaming them. Wallace (1993), drawing on the anthropological concept of the 'myth', analysed a debate about traditional and progressive educational practices identified in the UK Plowden Report. He states, 'Myths were created according to the news values of journalists, emphasizing selected messages stripped of the qualifying context set out in the evaluation report' (Wallace, 1993, p. 327). The use of newly released education reviews or reports are examples of common events that are the focus of media, and therefore media analysis. For example, Rawolle (2010) analysed the Batterham Review of Australia's science capability and Thomas (2006) an Australian school curriculum review known as the Wiltshire Review. A similar conceptualisation to the myth is the 'political spectacle'. Anderson (2007) suggests media use this to 'generate points of view, perceptions, anxieties, aspirations, and strategies to strengthen or undermine support for specific education policies, practices, and ideologies' (p. 103). However, Pettigrew and MacLure (1997) provide a word of caution, with their findings suggesting the 'press reporting of educational issues is frequently unfair are only partially substantiated' suggesting instead that they are more likely to 'inhibit debate through discourses of omission' (p. 392).

\section{Student assessments}

International large-scale student assessments frequently provide empirical data for a media analysis. This includes such the Programme for International Student Assessment (PISA), the Trends in International Mathematics and Science Study (TIMSS) assessment, and other local student assessments such as the UK General Certificate of Secondary Education (GCSE), the Australian National Assessment Program - Literacy and Numeracy (NAPLAN), and the US Common Core State Standards (CCSS). For example, Berliner and Biddle (1999) analyse the coverage of US results in the TIMSS assessment by print media, claiming the coverage of US public schools and schooling was biased, negative, simplistic, critical, lacked an understanding of the nature of schools and is ignorant of the effects of poverty and the distribution of opportunities in schooling that lead to student success. Warmington and Murphy (2004) analysed the UK media's concern over perceived falling standards in the Alevel examination, finding that reporting tended to be formulaic and prone towards 'producing ritualistic and polarized coverage' (p. 285). Mockler (2013) examined the editorial coverage of Australia's performance in standardised international literacy and numeracy tests and NAPLAN, and identified the narratives of distrust, choice and performance as prevalent in newspaper reportage on the topic. Finally, an analysis by Supovitz (2017), whose team has been engaged in research that tracked Twitter debates on the CCSS in the US since 2013 (see www.hashtagcommon core.com), shows that this social media platform is influential in education politics and policies. He states, 'During the Common Core debates, Twitter was a robust terrain for grassroots activists rather than one dominated by professional advocacy groups' indicating the increasing political influence of 
Baroutsis, A. (2019). Mapping the field of education research and media. In: Baroutsis, A., Riddle, S., and Thomson, P., Education research and the media: Challenges and possibilities (pp. 1-24). London: Routledge.

these groups and social media (Supovitz, 2017, p. 50).

Of all the student assessments, the PISA test draws the greatest interest in terms of empirical studies analysing media coverage; each with a slightly different focus. Stack (2006, 2007) reviews the Canadian press coverage of PISA, concluding that 'media interpreted these test results in concert with business and electoral elites as a "failure of marginalized students," rather than a failure of society to address systemic discrimination' (Stack, 2007, p. 100). Similarly, Takayama $(2008,2010,2013)$ analyses the role of national Japanese newspapers and the education department in 'mediating the potentially homogenising curricular policy pressure of globalisation exerted through the PISA league tables' (Takayama, 2008, p. 387). Elstad (2009, 2012) explores the press coverage and debate in Norwegian newspapers of the country's PISA performance, identifying blame management strategies deployed by education officials in an effort to 'avoid blame or displace it onto political opponents' (Elstad, 2012, p. 10). Likewise, Gur et al. (2012) critique the interpretation and utilisation of PISA results by the Turkish education authorities, suggesting decisions to proceed with curriculum reforms were made prior to the release of the PISA 2003 results, with these being used to justify the changes.

Most Australian media coverage of the country's PISA performance focused on quality, counting and comparing results "to provide "evidence" that was then used to comparatively position Australia against other countries' (Baroutsis and Lingard, 2017, p. 432). Yemini and Gordon (2017) suggest Israeli newspapers devote most of their attention to international examinations, rather than national examinations which are perceived as redundant. Grey and Morris (2018) demonstrate the distortion of the OECD's original messages by the UK government, and how media 'framed the results in terms of a narrative of decline, crisis and the need for urgent reform ... giving little coverage to either the recommended policy actions or the contrasting interpretations of the PISA results by politicians and the OECD' (p. 1). Steiner-Khamsi et al. (2018) analyse business-oriented US newspapers who see 'education as a profitable business opportunity' but perceive education as being in crisis with 'no correlation between spending and education outcome', while also expressing the value of 'school accountability, teacher performance, and decentralisation' for improving the quality of education (p. 190).

Understandably, analyses of a nation's performance in international large-scale student assessments are country based, with a number of scholars offering cross-country comparisons. For example, a comparison of PISA performance in Australian, Germany, and South Korea (Takayama, Waldow, \& Sung, 2013; Waldow et al., 2014); Germany and the USA (Martens \& Niemann, 2013); Norway, Sweden, and Finland (Fladmoe, 2011); France, Scotland, and Portugal (Pons, 2011); Japan, England, and France (Yasukawa, Hamilton, \& Evans, 2017).

\section{Schools, education systems and reforms}

This is a broad category covering numerous topics, and as such, has the largest grouping of publications. Across these publications, there is a focus on how traditional print and social media construct, or 'represent', education. This is not to say that representational ontologies are not problematic (Hayes \& Comber, 2017) in that researchers make sense of media data in particular ways through particular positionings. However, analyses of these discourses indicate media portrayals can be 'shallow depictions of educational issues' as Gerstl-Pepin (2002) found in an analysis of the 2000 US presidential election campaign and the candidates' views on education issues. She suggests that media portrayals of education tended to 'reinforce and reflect public assumptions that America's educational system is 
Baroutsis, A. (2019). Mapping the field of education research and media. In: Baroutsis, A., Riddle, S., and Thomson, P., Education research and the media: Challenges and possibilities (pp. 1-24). London: Routledge.

failing' (Gerstl-Pepin, 2002, p. 37). Similarly, Baker (1994) notes media coverage of education is often 'negative and derisory' (p. 286). This trend is evident in today's media coverage, elsewhere I found it is often 'negative, critical, oppressive, and reductionist' (Baroutsis, 2016, p. 567) and that there is a focus on the decline of standards and quality in education (Baroutsis \& Lingard, 2017).

School standards were covered by a number of publications. For example, Ronnberg et al. (2013) investigate the Swedish school inspection activities, framed within understandings of an audit culture. School standards were sometimes framed around larger social issues. For example, MacMillan (2002) investigated the types of events that attract media attention, suggesting that these followed a particular 'recurring patterns and themes' that these were 'generalized as a feature of all British schools' (p. 36). Robert (2012) suggests newspapers are a 'site of contestation' where debates over global reforms are 'contextualised in "obvious" and "natural" local language' (p. 2). In particular, media attention often reaches a frenzy when there are proposed changes to school practices and reforms. For example, Snyder $(2008,2009)$ outlines literacy reforms, particularly the phonics debate, that have attracted a multitude of media attention.

At times, these media perceptions are presented as common-sensical and self-evident 'facts' about education. This is not a statement intended to understate the agency of the reader, but as Bernard Cohen (1963) states, 'The press is significantly more than a purveyor of information and opinion', adding, 'It may not be successful much of the time in telling people what to think, but it is stunningly successful in telling its readers what to think about' (p. 13). Alarmingly, such coverage does incite moral panics. As Stanley Cohen (2002) states, mass media are 'carriers' and 'producers' of moral panic. Unfortunately, when moral panic about education in crisis is circulated, 'more moral panics will be generated' (Cohen, 2002, p. 233).

Inevitably, moral panics promote and encourage media to proffer solutions to the problems. A number of publications analyse what are often presented as ways of averting these crises, but often become problematic in themselves. For example, Haas (2007), when analysing media constructions of think tanks, suggests 'news media presented all the think tanks as credible sources of research, facts, and figures on education' (p. 63). Other studies include a focus on multinational edu-businesses (Hogan, 2015), the 'Teach for ...' movement (Brewer \& Wallis, 2015; Faltin Osborn \& Sierk, 2015), marketisation (Goldstein \& Chesky, 2016), and privatisation (Shuffelton, 2015).

The publications related to schools, education systems and reform also highlight the included voices, and perhaps more importantly, identify those that are excluded from debates about education (also see Chapter 7). This is an area with the field of education research and media that urgently needs further research. Thomas (1999) notes which stakeholders are given the authority to speak about education; finding it was predominantly ministers of education rather than teachers (p. 41). Similarly, Gill (1994) analysed media roles in curriculum change, suggesting there is an absence of professional voices in the debates, with these voices often being conveyed as the 'drama of dissonant and often acrimonious voices' (p. 111). Other often excluded voices are those of children and young people (also see Chapter 2). For example, Chesky and Goldstein (2016) analysed the presence of girls' voices in news reports about STEM education reform in the US, while Mills (2004) found the press constructed boys as 'the new disadvantaged' (p. 344). It is not surprising then, that Robert (2012) found that traditional print media pushed particular gendered education agendas (also see Chapter 5). Exclusion can also occur when the perspectives of various cultural and racial minority groups are not identified or when the stereotypical constructions become the normalised (Hall \& Smith, 2012; Hussain \& Stern, 2015) (also see Chapters 4 and 9). 
Baroutsis, A. (2019). Mapping the field of education research and media. In: Baroutsis, A., Riddle, S., and Thomson, P., Education research and the media: Challenges and possibilities (pp. 1-24). London: Routledge.

Drawing on the notion of excluded voices, some publications focused on activism as a means of demonstrating how groups of people and organisations rally together to find a forum to express their concerns and affect change. This is particularly evident in the social media publications. For example, Cabalin (2014) writes about the 2011 Chilean student movement, identifying these as, 'The most important social protests in Chile's recent history, where young people played a leading role in the discussion over education' (p. 25). Similarly, Avigur-Eshel and Berkovich (2017) analyses middle-class parent activism as a means of addressing political inequality and enabling participation in policy debates.

Teachers' work

The aspects of teachers' work addressed in the publications in this thematic group include: constructions of teachers and teachers' social media usage.

First, publications that address constructions of teachers and their work are predominantly covered through traditional print media articles. These cover a range of topics. For example, Hansen (2009) investigates UK regional newspapers' reporting of teachers suggesting portrayals move from a 'negative view of teachers as troublesome to a more positive emphasis on teachers as a hardworking profession besieged by mounting pressures' (p. 335). In the US, Cohen (2010) found that teachers are portrayed in terms of discourses of accountability and caring, while Ulmer (2016) found the press reinforced that teacher quality is in crisis. In Australia, Keogh and Garrick (2011) found media discourses contributed towards negative public opinion about teacher quality. In Sweden, Edling (2015) found that the press generally spoke about teachers in over-simplified stereotypes such as the 'good' or 'bad' teacher, ignoring the relational and job complexity of teachers' work. Zemke (2007) found a similar situation in the UK where the press exaggerated the positive and negative aspects of teachers' work. Punakallio and Dervin (2015) identify counternarratives to international perceptions of Finnish teachers being 'the best' suggesting these discourses were 'overly positive, uncritical and somewhat naïve' (p. 318). Constructions of teachers also extended to unionism and industrial action. For example, Greenberg (2004) investigates the 1997 Ontario teachers' strike; Goldstein (2011) analyses media perceptions of teachers' unions finding media reporting about these to be immensely negative.

The second aspect of teachers' work is evident predominantly through studies drawing on or about social media, and investigating teachers' use of social media (also see Chapter 10). For example, research by Carpenter and Krutka (2014, 2015); Goodyear, Casey, and Kirk (2014); Holmes, Preston, Shaw, and Buchanan (2013); Moreillon (2015); Visser, Evering, and Barrett (2014) found teachers used microblogging environments such a Twitter as professional development, enabling them to 'access novel ideas and stay abreast of education advances and trends, particularly regarding educational technology' (Carpenter \& Krutka, 2015, p. 707). Sauers and Richardson (2015) analyse school leaders' use of Twitter, finding tends to be used for 'educational purposes and as a way to create communities of practice focused on educational issues' (p. 127). Other than investigating teachers' professional development usage of social media, other studies such as Shiller (2015) analyses the utility of social media, particularly teacher-authored blogs, finding these enabled 'individuals to speak back to neoliberal discourses by providing a space to critique media and to present a counter-narrative to what media has presented' thereby reframing the teacher quality debates (p. 1). However, Veletsianos and Kimmons (2016) suggest that researchers' focus on social media has 'only examined a fragment of scholars' online activities, possibly ignoring other areas of online presence' (p. 1). 
Baroutsis, A. (2019). Mapping the field of education research and media. In: Baroutsis, A., Riddle, S., and Thomson, P., Education research and the media: Challenges and possibilities (pp. 1-24). London: Routledge.

\section{Children and young people}

This thematic group is one of the smallest and demonstrates an area where further research is required. The most recent of these publications is by Taylor (2018) who conducted a content analysis of Australian newspaper reporting on drug testing in schools, framed through discourses of 'public good'. A Canadian study by Gardam and Giles (2016), compared the framing of the deaths of seven First Nations students in non-First Nations and First Nations news sources. In another study, Kelly (2006) considers mainstream media frames of 'troubled and troubling youth' and the imagery conveyed through discourses of 'inner-city youth as "gang bangers"; teen mothers as "children having children" and "welfare bums"; and girls as fashion obsessed and impressionable' (p. 27).

\section{Future considerations}

This archive of literature about education research and media was systematically generated drawing on specific inclusion criteria. Even so, it is a vast and complex corpus, drawing on both traditional print and social media across the globe. I have chosen to review these publications drawing on the standard research frames of the theoretical, methodological, and empirical aspects of research in an effort to identify the progress in the field. While it is difficult to write a conclusion that summarise this corpus of literature about education research and media, I have elected to provide some insights and propose future directions for research in the field of education research and media, drawing on three aspects: critique, representation and voice.

First, as an emerging field of research, it is understandable that there is a focus on exploring and understanding the media logics of practice and the mediatisation of education, and as such, much of the literature has focused on critique. Unfortunately, such critique can take on a problematic approach that focuses on evaluative judgments intent on 'fault finding' (Williams, 1976, p. 75) or essentialist perspectives that incorporate notion of the 'good' and the 'bad'. Alternatively, if critique can be viewed as a 'practice' (Williams, 1976; Foucault, 1997). Foucault (1997) suggests, 'there is something in critique which is akin to virtue' (p. 43) and as such, there is scope within such understandings to take up a more radical approach that takes a critically stance towards preestablished norms (Butler, 2001). As such, research critique of media reporting and practices provides valuable insights into journalistic practices for both educators and those in areas of media communication. However, it is timely for scholars to consider moving beyond simply a critique of media reporting of education and consider the more generative and productive aspects of research in this area. That is, rather than an analysis of 'the problem', future research could expand to consider solutions and interventions; counter-narratives and approaches; and resistance and activism; thereby providing pathways for improvement and change.

Secondly, established scholarship in the field of education research and media tends to draw on the problematic notion of representation. From a research perspective, researchers are inevitably part of the research process and therefore even the most critical and reflexive researcher, makes sense of data in particular ways (Hayes and Comber, 2017) and therefore becomes part of the phenomena being studied. At times, this may privilege certain understandings and perspectives over others (Barad, 2007). Instead of understanding media practices through representations of education, other approaches include 'discourses' (Foucault, 1972) or 'performances' (Barad, 2007). Barad (2007) suggests that performative approaches 'call into question the basic premises of representationalism and focus inquiry on the practices or performances of representing, as well as on the productive effects of those 
Baroutsis, A. (2019). Mapping the field of education research and media. In: Baroutsis, A., Riddle, S., and Thomson, P., Education research and the media: Challenges and possibilities (pp. 1-24). London: Routledge.

practices and the conditions for their efficacy' (Barad, 2007, p. 28). While I suspect that many of the articles in this archive do focus on discourses and performative approaches, the use of terms such as 'representation', without providing a detailed explanation of the theoretical and/or methodological perspectives, means there is scope for misunderstanding and conjecture.

Finally, there is scope for scholarship in education research and media to more actively focus on the excluded voices and practices that can promote inclusion. Couldry (2010) suggests that "voice is undermined by rationalities which take no account of voice and by practices that exclude voice or undermine forms for its expression' (p. 15).

Representational thinking often overlooks those excluded in traditional and social media, making this, by far, the most difficult to implement. Additionally, both education and media research are unlikely to be able to sway institutional and organisation-specific practices in journalism, given this is a profit-driving industry. However, a momentum in research that provides recommendations and solutions to policy makers is more likely to gain outcomes, particularly when these practices of inclusion are modelled by governments, education jurisdictions, and schools.

In this chapter, I have provided an historical, statistical and thematic account of the archive of publications in this emerging field of education research and media. As scholarship moves forward, I suggest there is a move beyond critique and representation to more generative approaches that incorporate inclusive solutions, resistances, and voices. Therefore, I end this chapter by again, drawing on a quote by Pat Thomson as it appeared in the first special issue on the topic and is a fitting close to this chapter. Thomson (2004, p. 252) states: 'Bringing a corpus together begins to mark out a territory, a specific topology of research ... It is a landscape waiting further exploration'. As evidenced by this review of the literature, scholarship in the field of education research and media has certainly marked out a territory.

\section{References}

Adhikary, R. W., Lingard, B., \& Hardy, I. (2018). A critical examination of Teach for Bangladesh's Facebook page: 'Social-mediatisation' of global education reforms in the 'post-truth' era. Journal of Education Policy, 33(5), 632-661.

Alhamdan, B., Al-Saadi, K., Baroutsis, A., du Plessis, A., Hamid, O. M., \& Honan, E. (2014). Media representation of teachers across cultures in a globalised world. Comparative Education, 50(4), 490-505.

Anderson, G. L. (2007). Media's impact on educational policies and practices: Political spectacle and social control. Peabody Journal of Education, 82(1), 103-120.

Avigur-Eshel, A., \& Berkovich, I. (2017). Who 'likes' public education: Social media activism, middle-class parents, and education policy in Israel. British Journal of Sociology of Education, O(0). doi:10.1080/01425692.2017.1418294

Baker, M. (1994). Media coverage of education. British Journal of Educational Studies, 42(3), 286-297.

Barad, K. (2007). Meeting the universe halfway: Quantum physics and the entanglement of matter and meaning. Durham: Duke University Press.

Baroutsis, A. (2016). Media accounts of school performance: Reinforcing dominant practices of accountability. Journal of Education Policy, 31(5), 567-582.

Baroutsis, A. (2017). Understanding media mentalities and logics: Institutional and journalistic practices, and the reporting of teachers' work. Discourse: Studies in the Cultural Politics of Education, 0(0), 1-15. doi:10.1080/01596306.2017.1399861 
Baroutsis, A. (2019). Mapping the field of education research and media. In: Baroutsis, A., Riddle, S., and Thomson, P., Education research and the media: Challenges and possibilities (pp. 1-24). London: Routledge.

Baroutsis, A., \& Lingard, B. (2017). Counting and comparing school performance: an analysis of media coverage of PISA in Australia, 2000-2014. Journal of Education Policy, 32(4), 432-449.

Berliner, D. C., \& Biddle, B. J. (1999). The awful alliance of the media and public-school critics. The Education Digest, 64(5), 4-10.

Blackmore, J., \& Thomson, P. (2004). Just 'good and bad news'? Disciplinary imaginaries of head teachers in Australian and English print media. Journal of Education Policy, 19(3), 301-320.

Blackmore, J., \& Thorpe, S. (2003). Media/ting change: The print media's role in mediating education policy in a period of radical reform in Victoria, Australia. Journal of Education Policy, 18(6), 577-595.

Bourdieu, P. (2011). On television. Cambridge, UK: Polity.

Brewer, J. T., \& Wallis, M. (2015). \#TFA: The intersection of social media and education reform. Critical Education, 6(13), 1-17.

Butler, J. (2001). What is critique? An essay on Foucault's virtue. European Institute for Progressive Cultural Policies. Retrieved from http://eipcp.net/transversal/0806/butler/en/\#_ftnref2

Cabalin, C. (2014). Online and mobilized students: The use of Facebook in the Chilean student protests. Comunicar, 43(XXII), 25-33.

Cabalin, C. (2015). Mediatizing higher education policies: Discourses about quality education in the media. Critical Studies in Education, 56(2), 224-240.

Carpenter, J. P., \& Krutka, D. G. (2014). How and why educators use Twitter: A survey of the field. Journal of Research on Technology in Education, 46(4), 414-434.

Carpenter, J. P., \& Krutka, D. G. (2015). Engagement through microblogging: Educator professional development via Twitter. Professional Development in Education, 41(4), 707-728.

Chesky, N. Z., \& Goldstein, R. A. (2016). Whispers that echo: Girls' experiences and voices in news media reports about STEM education reform. Journal for Critical Education Policy Studies, 14(2), 130-157.

Cohen, B. (1963). The press and foreign policy. Princeton, N.J: Princeton University Press.

Cohen, J. L. (2010). Teachers in the news: A critical analysis of one US newspaper's discourse on education, 2006-2007. Discourse: Studies in the Cultural Politics of Education, 31(1), 105-119.

Cohen, S. (2002). Folk devils and moral panics: The creation of the Mods and Rockers. London: Routledge.

Couldry, N. (2010). Why voice matters: Culture and politics after neoliberalism. Los Angeles: SAGE.

Cunningham, P. (1992). Teachers' professional image and the press 1950-1990. History of Education, 21(1), 37-56.

Cunningham, S. (2010). Policy. In S. Cunningham \& G. Turner (Eds.), The media and communications in Australia (3 ed., pp. 31-48). Crows Nest: Allen \& Unwin.

Edling, S. (2015). Between curriculum complexity and stereotypes: Exploring stereotypes of teachers and education in media as a question of structural violence. Journal of Curriculum Studies, 47(3), 399-415.

Elstad, E. (2009). Schools which are named, shamed and blamed by the media: school accountability in Norway. Educational Assessment, Evaluation and Accountability, 21(2), 173-189.

Elstad, E. (2012). PISA debates and blame management among the Norwegian educational authorities: Press coverage and debate intensity in the newspapers. Problems of Education in the 21st century, 48, 10-22. 
Baroutsis, A. (2019). Mapping the field of education research and media. In: Baroutsis, A., Riddle, S., and Thomson, P., Education research and the media: Challenges and possibilities (pp. 1-24). London: Routledge.

Entman, R. M. (1993). Framing: Toward clarification of a fractured paradigm. Journal of Communication, 43(4), 51-58.

Esser, F., \& Stromback, J. (Eds.). (2014). Mediatization of politics: Understanding the transformation of Western democracies. Houndmills, UK: Palgrave Macmillan.

Fairclough, N. (2010). Critical Discourse Analysis: The critical study of language. London: Routledge.

Faltin Osborn, S. R., \& Sierk, J. L. (2015). Teach For America in the media: A multimodal semiotic analysis. Critical Education, 6(16), 1-18.

Fenech, M., \& Wilkins, D. P. (2017). Representations of childcare in the Australian print media: An exploratory corpus-assisted discourse analysis. Australian Educational Researcher, 44(2), 161-190.

Fladmoe, A. (2011). Education in the news and in the mind: PISA, news media and public opinion in Norway, Sweden and Finland. Nordicom Review, 32(2), 99-116.

Ford, D. R., Porfilio, B., \& Goldstein, R. A. (2015). The news media, education and the subversion of the neoliberal social imaginary. Critical Education, 6(7), 1-24.

Foucault, M. (1972). The archaeology of knowledge and the discourse on language (A. M. Sheridan-Smith, Trans.). New York: Vintage Books.

Foucault, M. (1997). What is critique? In S. Lotringer \& L. Hochroth (Eds.), The politics of truth: Michel Foucault (pp. 23-82). New York: Semiotext(e).

Franklin, B. (2004). Education, education and indoctrination! Packaging politics and the three 'Rs'. Journal of Education Policy, 19(3), 255-270.

Gardam, K., \& Giles, A. R. (2016). Media representations of policies concerning education access and their roles in seven First Nations students' deaths in Northern Ontario. The International Indigenous Policy Journal, 7(1), np.

Gerstl-Pepin, C. I. (2002). Media (mis)representations of education in the 2000 presidential election. Educational Policy, 16(1), 37-55.

Gerstl-Pepin, C. I. (2007). Introduction to the special issue on the media, democracy, and the politics of education. Peabody Journal of Education, 82(1), 1-9.

Gewirtz, S., Dickson, M., \& Power, S. (2004). Unravelling a 'spun' policy: A case study of the constitutive role of 'spin' in the education policy process. Journal of Education Policy, 19(3), 321-342.

Gill, M. (1994). Who framed english? A case study of the media's role in curriculum change. Critical Studies in Education, 35(1), 96-113.

Goffman, E. (1986). Frame analysis: An essay on the organization of experience. Boston: Northeastern University Press.

Goldstein, R. A. (2011). Imaging the frame: Media representations of teachers, their unions, NCLB, and education reform. Educational Policy, 25(4), 543-576.

Goldstein, R. A., \& Chesky, N. Z. (2016). A twenty-first century education: The marketization and mediatization of school reform discourses. In Z. C. Wubbena, D. R. Ford, \& B. Porfilio (Eds.), News media and the neoliberal privatization of education (pp. 25-44). Charlotte, NC: Information Age Publishing.

Goodyear, V. A., Casey, A., \& Kirk, D. (2014). Tweet me, message me, like me: Using social media to facilitate pedagogical change within an emerging community of practice. Sport, Education and Society, 19(7), 927-943.

Gorton, R. (1979). What do Principals think of news media coverage? NASSP Bulletin, 63(431), 116-118.

Greenberg, J. (2004). Tories, teachers and the media politics of education reform: News discourse and the 1997 Ontario teachers' strike. Journalism Studies, 5(3), 353-371.

Grey, S., \& Morris, P. (2018). PISA: multiple 'truths' and mediatised global governance. Comparative Education, 54(2), 109-131. 
Baroutsis, A. (2019). Mapping the field of education research and media. In: Baroutsis, A., Riddle, S., and Thomson, P., Education research and the media: Challenges and possibilities (pp. 1-24). London: Routledge.

Gur, B. S., Celik, Z., \& Ozoglu, M. (2012). Policy options for Turkey: A critique of the interpretation and utilization of PISA results in Turkey. Journal of Education Policy, 27(1), 1-21.

Haas, E. (2007). False equivalency: Think tank references on education in the news media. Peabody Journal of Education, 82(1), 63-102.

Hall, H. R., \& Smith, E. L. (2012). 'This is not reality ... it's only TV': African American girls respond to media (mis)representations. The New Educator, 8(3), 222-242.

Hansen, A. (2009). Researching 'teachers in the news': The portrayal of teachers in the British national and regional press. Education 3-13, 37(4), 335-347.

Hattam, R., Prosser, B., \& Brady, K. (2009). Revolution or backlash? The mediatisation of education policy in Australia. Critical Studies in Education, 50 (2), 159-172.

Hayes, D., \& Comber, B. (2017). Researching pedagogy in high poverty contexts: Implications of non-representational ontology. International Journal of Research \& Method in Education, O(0). doi:10.1080/1743727X.2017.1395409

Hepp, A. (2013). Cultures of mediatization. Cambridge, UK: Polity.

Hepp, A., Brieter, A., \& Hasebrink, U. (Eds.). (2018). Communicative figurations: Transforming communications in times of deep mediatization. Gewerbestrasse, Switzerland: Palgrave Macmillan.

Hogan, A. (2015). Boundary spanners, network capital and the rise of edu-businesses: The case of News Corporation and its emerging education agenda. Critical Studies in Education, 56(3), 301-314.

Holmes, K., Preston, G., Shaw, K., \& Buchanan, R. (2013). 'Follow' me: Networked professional learning for teachers. Australian Journal of Teacher Education, 38(12), 55-65.

Hussain, K., \& Stern, M. (2015). Lessons from the 'Pen alongside the sword': School reform through the lens of radical Black press. Critical Education, 6(7), 25-43.

Kelly, D. M. (2006). Frame work: Helping youth counter their misrepresentations in media. Canadian Journal of Education, 29(1), 27-48.

Keogh, J., \& Garrick, B. (2011). Creating catch 22: Zooming in and zooming out on the discursive constructions of teachers in a news article. International Journal of Qualitative Studies in Education, 24(4), 419-434.

Klinger, U., \& Svensson, J. (2015). The emergence of network media logic in political communication: A theoretical approach. New Media \& Society, 17(8), 1241-1257.

Krippendorff, K. (2013). Content analysis: An introduction to its methodology. London: SAGE.

Lingard, B., \& Rawolle, S. (2004). Mediatizing educational policy: The journalistic field, science policy, and cross-field effects. Journal of Education Policy, 19(3), 361-380.

Luehmann, A. L. (2008). Blogs' affordances for identity work: Insights gained from an urban teacher's blog. The New Educator, 4(3), 175-198.

MacMillan, K. (2002). Narratives of social disruption: Education news in the British tabloid press. Discourse: Studies in the Cultural Politics of Education, 23(1), 27-38.

Martens, K., \& Niemann, D. (2013). When do numbers count? The differential impact of the PISA rating and ranking on education policy in Germany and the US. German Politics, 22(3), 314-332.

Mayer-Schönberger, V., \& Cukier, K. N. (2013). Big data: A revolution that will transform how we live, work, and think. Boston: Houghton Mifflin Harcourt.

Mazzoleni, G. (2008). Mediatization of society. In W. Donsbach (Ed.), The International Encyclopedia of Communication (pp. 1-5). Malden, MA: Blackwell. 
Baroutsis, A. (2019). Mapping the field of education research and media. In: Baroutsis, A., Riddle, S., and Thomson, P., Education research and the media: Challenges and possibilities (pp. 1-24). London: Routledge.

Mazzoleni, G. (2015). Towards an inclusive digital public sphere. In S. Coleman, G. Moss, \& K. Parry (Eds.), Can the media serve democracy (pp. 174-183). New York: Palgrave Macmillan.

Mazzoleni, G. (2017). Changes in contemporary communication ecosystems ask for a 'new look' at the concept of mediatisation. Javnost - The Public, 24(2), 136-145.

Mills, M. (2004). The media, marketing, and single sex schooling. Journal of Education Policy, 19(3), 343-360.

Mockler, N. (2013). Reporting the 'education revolution': MySchool.edu.au in the print media. Discourse: Studies in the Cultural Politics of Education, 34(1), 1-16.

Moreillon, J. (2015). \#schoollibrarians Tweet for professional development: A netnographic case study of \#txlchat. School Libraries Worldwide, 21(2), 127-137.

Murphy, R. (2013). Media roles in influencing the public understanding of educational assessment issues. Oxford Review of Education, 39(1), 139-150.

Pettigrew, M., \& MacLure, M. (1997). The press, public knowledge and the grant maintained schools policy. British Journal of Educational Studies, 45(4), 392-405.

Phelan, S., \& Salter, L. A. (2017). The journalistic habitus, neoliberal(ized) logics, and the politics of public education. Journalism Studies, 0(0), 1-19.

doi:10.1080/1461670X.2017.1370976

Pons, X. (2011). What do we really learn from PISA? The sociology of its reception in three European countries (2001-2008). European Journal of Education, 46(4), 540-548.

Punakallio, E., \& Dervin, F. (2015). The best and most respected teachers in the world? Counternarratives about the 'Finnish miracle of education' in the press. Power $\&$ Education, 7(3), 306-321.

Rawolle, S. (2005). Cross-field effects and temporary social fields: A case study of the mediatization of recent Australian knowledge economy policies. Journal of Education Policy, 20(6), 705-724.

Rawolle, S. (2010). Understanding the mediatisation of educational policy as practice. Critical Studies in Education, 51(1), 21-39.

Rawolle, S., \& Lingard, B. (2010). The mediatization of the knowledge based economy: An Australian field based account. Communications: The European Journal of Communication Research, 35(3), 269-286.

Rawolle, S., \& Lingard, B. (2014). Mediatization and education: A sociological account. In K. Lundby (Ed.), Mediatization of communication (Vol. 21, pp. 595-614). Berlin: De Gruyter.

Robert, S. A. (2012). (En)gendering responsibility: A critical news analysis of Argentina's education reform, 2001-2002. Discourse: Studies in the Cultural Politics of Education, 33(4), 485-498.

Ronnberg, L., Lindgren, J., \& Segerholm, C. (2013). In the public eye: Swedish school inspection and local newspapers: exploring the audit-media relationship. Journal of Education Policy, 28(2), 178-197.

Sauers, N. J., \& Richardson, J. W. (2015). Leading by following: An analysis of how K-12 school leaders use Twitter. NASSP Bulletin, 99(2), 127-146.

Shiller, J. (2015). Speaking back to the neoliberal discourse on teaching: How U.S. teachers use social media to redefine teaching. Critical Education, 6(9), 1-17.

Shuffelton, A. (2015). Re-privatizing the family: How 'opt-out' and 'parental involvement' media narratives support school privatization. Critical Education, 6(12), 1-15.

Snyder, I. (2008). Literacy Wars: Why teaching children to read and write is a battleground in Australia. Crows Nest, AU: Allen \& Unwin.

Snyder, I. (2009). The stories that divide us: Media (mis)representations of literacy education. English in Australia, 44(1), 13-23. 
Baroutsis, A. (2019). Mapping the field of education research and media. In: Baroutsis, A., Riddle, S., and Thomson, P., Education research and the media: Challenges and possibilities (pp. 1-24). London: Routledge.

Stack, M. (2006). Testing, testing, read all about it: Canadian press coverage of the PISA results. Canadian Journal of Education, 29(1), 49-69.

Stack, M. (2007). Representing school success and failure: Media coverage of international tests. Policy Futures in Education, 5(1), 100-110.

Stack, M. (2016). Global university rankings and the mediatization of higher education. Houndmills, UK: Palgrave Macmillan.

Steiner-Khamsi, G., Appleton, M., \& Vellani, S. (2018). Understanding business interests in international large-scale student assessments: A media analysis of The Economist, Financial Times, and Wall Street Journal. Oxford Review of Education, 44(2), 190203.

Stephens, M. (2007). A history of news (3 ed.). New York: Oxford University Press.

Supovitz, J. (2017). Social media is the new player in the politics of education. Kappan, 99(3), 50-55.

Takayama, K. (2008). The politics of international league tables: PISA in Japan's achievement crisis debate. Comparative Education, 44(4), 387-407.

Takayama, K. (2010). Politics of externalization in reflexive times: Reinventing Japanese education reform discourses through 'Finnish PISA success'. Comparative Education Review, 54(1), 51-75.

Takayama, K. (2013). Untangling the global-distant-local knot: The politics of national academic achievement testing in Japan. Journal of Education Policy, 28(5), 657-675.

Takayama, K., Waldow, F., \& Sung, Y.-K. (2013). Finland has it all? Examining the media accentuation of 'Finnish Education' in Australia, Germany and South Korea. Research in Comparative and International Education, 8(3), 307-325.

Taylor, E. (2018). Student drug testing and the surveillance school economy: An analysis of media representation and policy transfer in Australian schools. Journal of Education Policy, 33(3), 383-397.

Thapliyal, N. (2018). \#Eduresistance: A critical analysis of the role of digital media in collective struggles for public education in the USA. Globalisation, Societies and Education, 16(1), 49-65.

Thomas, S. (1999). Who speaks for education? One newspaper's reporting of a review of the Queensland school curriculum. Discourse: Studies in the Cultural Politics of Education, 20(1), 41-56.

Thomas, S. (2006). Education policy in the media: Public discourses on education. Teneriffe, AU: Post Pressed.

Thomson, P. (2004). Introduction. Journal of Education Policy, 19(3), 251-253.

Thomson, P., Blackmore, J., Sachs, J., \& Tregenza, K. (2003). High stakes principalshipsleepless nights, heart attacks and sudden death accountabilities: Reading media representations of the United States principal shortage. Australian Journal of Education, 47(2), 118-132.

Ulmer, J. B. (2016). Re-framing teacher evaluation discourse in the media: An analysis and narrative-based proposal. Discourse: Studies in the Cultural Politics of Education, 37(1), 43-55.

van Dijck, J. (2013). The culture of connectivity: A critical history of social media. New York, NY: Oxford University Press.

Veletsianos, G., \& Kimmons, R. (2016). Scholars in an increasingly open and digital world: How do education professors and students use Twitter? Internet and Higher Education, 30(July), 1-10.

Visser, R. D., Evering, L. C., \& Barrett, D. E. (2014). \#TwitterforTeachers: The implications of Twitter as a self-directed professional development tool for $\mathrm{K}-12$ teachers. Journal of Research on Technology in Education, 46(4), 396-413. 
Waldow, F., Takayama, K., \& Sung, Y.-K. (2014). Rethinking the pattern of external policy referencing: Media discourses over the "Asian Tigers" PISA success in Australia, Germany and South Korea. Comparative Education, 50(3), 302-321.

Wallace, M. (1993). Discourse of derision: The role of the mass media within the education policy process. Journal of Education Policy, 8(4), 321-337.

Warmington, P., \& Murphy, R. (2004). Could do better? Media depictions of UK educational assessment results. Journal of Education Policy, 19(3), 285-299.

Williams, R. (1976). Keywords. New York: Oxford University Press.

Wubbena, Z. C., Ford, D. R., \& Porfilio, B. J. (Eds.). (2016). News media \& the neoliberal privatization of education. Charlotte, NC: Information Age Publishing.

Yasukawa, K., Hamilton, M., \& Evans, J. (2016). A comparative analysis of national media responses to the OECD Survey of Adult Skills: policy making from the global to the local? Compare: A Journal of Comparative and International Education, 47(2), 271285.

Yemini, M., \& Gordon, N. (2017). Media representations of national and international standardized testing in the Israeli education system. Discourse: Studies in the Cultural Politics of Education, 38(2), 262-276.

Zemke, E. (2007). Embracing complexity: Findings from a comparative analysis of representations of teachers in the British press and research literature. Education Research and Perspectives, 34(1), 27-56. 